\title{
EDITORIAL
}

\section{Moving online and keeping a distance: Danish reaction to challenges when working in pharmacies or training to be a pharmaconomist during COVID-19}

\author{
Christina Durinck ${ }^{1}$, Elsebeth Hagen ${ }^{2}$ \\ ${ }^{1}$ The Danish Association of Pharmaconomists, Denmark \\ ${ }^{2}$ The Pharmacological Association, Denmark
}

\author{
Correspondence \\ Christina Durinck \\ The Danish Association of Pharmaconomists \\ Ramsingsvej 30 \\ 2500 Valby \\ Denmark \\ ff@farmakonom.dk
}

\begin{abstract}
This article describes the workforce and educational challenges faced by pharmaconomists in Denmark as a consequence of the first wave of the COVID-19 pandemic. In Danish pharmacies, pharmaconomists make up the majority of the staff. They hold a higher level of qualification than the general European pharmacy technician, more comparable to that of a Bachelor's degree. In the community pharmacies, pharmaconomists worked long hours and faced new questions and a change in behaviour by the public due to the pandemic. An emergency agreement between The Danish Association of Pharmaconomists and the Association of Danish Pharmacies made flexible planning possible, and guidelines with recommendations meant that most community pharmacies ended up introducing safety measures. In hospitals, pharmaconomists were directly engaged in deciding which kinds of medicine to stock up on to help the COVID-19 patients as they were admitted to hospital. A high level of cooperation and the slashing of red tape made things run relatively smooth. The training of pharmaconomist students went online in spring of 2020, as did exams. It required planning, as did the return to physical school activities as well as CPE in the autumn of 2020 .
\end{abstract}

From the outset, the Danish government's approach to the 2020 COVID-19 pandemic was to 'go big and go fast' (Wammen, 2020). On the 11th March, Prime Minister Mette Frederiksen issued a national lockdown to come into effect by 16th March. The lockdown included the closure of education facilities and childcare institutions, gatherings of more than 100 persons becoming prohibited, non-essential workers in the public sector being furloughed or asked to work from home, and the workforce in the private sector being encouraged to do the same. The goal was to stop the spread of the COVID-19 virus whilst keeping vital functions and large parts of society's production in motion (Wammen, 2020). The lockdown proved efficient, but as the easing of the lockdown began in mid-April, the prime minister warned that the Danish society would be locked in what is referred to as the "Hammer and Dance Strategy" for a long time. That means that after easing of the initial hard lockdown, society would - in the foreseeable future experience localised lockdowns if and when outbreaks occur.

In Danish pharmacies, pharmaconomists make up the majority of the staff. They hold a higher level of qualification than the general European pharmacy technician, more comparable to that of a Bachelor's degree. Pharmaconomists are also employed at hospitals, where they manage medicine rooms and perform 
anamnesis (patient medical history taking). They are thus critical to the functioning of both community and hospital pharmacies.

\section{Pharmaconomists, COVID-19, and the workplace}

\section{Safety in the workplace}

From the outset, the authorities issued guidelines detailing that hand sanitiser should be available throughout the commercial sector, and it should be ensured that customers kept a safe distance from both each other and staff (often termed social distancing) (Danish Health Authority, 2020). With pharmacies comprising a significant component of the front line in the healthcare sector, reactions varied. Over the initial weekend, some pharmacies installed plexiglass screens for their counters and put up signs to encourage caution amongst customers. New work schedules were issued to ensure that pharmaconomists did not work at multiple pharmacy units in order to reduce the infection risk in the local workforce (Hagen, 2020a). Others scrambled to reorganise. After a few weeks with a widespread lack of adequate action from some employers, the pharmacies received guidelines and general recommendations from the Association of Danish Pharmacies, backed by the unions of both pharmacists and pharmaconomists (Kahns et al., 2020). As a consequence, most pharmacies finally introduced various safety precautions as those mentioned above.

\section{Cooperation - making things work}

In March 2020, the Danish Association of Pharmaconomists entered into a temporary emergency agreement with the Association of Danish Pharmacies, allowing a more flexible day-to-day planning of the worksheets/holidays of pharmaconomists (The Danish Association of Pharmaconomists, 2020). The heavy pressure on the pharmacies, and the extraordinary situation in general, made it clear that - as a part of the Danish healthcare system pharmaconomists and their union had to show a great amount of responsibility towards society.

\section{New roles for Danish pharmaconomists}

Danish pharmaconomists in both community pharmacies and hospitals experienced a heavy workload during the outbreak of COVID-19. This meant that the pharmaconomists had to deal with a broader range of health-related questions. Pharmacies also faced problems with civilians hoarding medicines and hand sanitiser products.

In the hospital sector, some pharmaconomists were part of the overall emergency response. That meant picking up any available information from countries that had dealt with COVID-19 prior to the Danish outbreaks and translating this into which drugs/medicines were needed in the supply chain (Hagen, 2020b). The extraordinary situation made cooperation run smoothly, with red tape being slashed and everyone bringing their utmost to the fore (Hagen, 2020c).

\section{Effects of COVID-19 on the education of pharmaconomists in Denmark}

In Denmark, the education of pharmaconomist students is comprised of two elements: on-the-job learning and longer periods at the pharmaconomist school with live-in facilities.

As lockdown was gradually edging closer in early March 2020, a group of students in their final year had just arrived at school but they were sent home a few hours before Prime Minister Frederiksen announced the lockdown (Fonnesbæk, 2020a).

\section{Converting to online education}

Within a short period, education moved online. All pharmaconomist students are routinely issued a laptop for educational purposes with Office 365 pre-installed. Denmark has a high degree of Internet connectivity, so access to the Internet was not a problem. However, general lockdown posed a problem for some students. Some students spent their designated school time at their residence pharmacies in order to avoid the general chaos at home made up by spouses working from home and childcare logistics as kindergartens and schools temporarily shut down (Fonnesbæk, 2020b).

Rapidly, all classes were converted into webinars. The number of webinars was doubled in order to make more students able to attend and to ask questions. All webinars were available for streaming. This put a great deal of strain on teachers who were facing both new means of interacting with students and an increase in workload (Fonnesbæk, 2020b).

It was also taken into account that the didactic needs of students in their final year differed from those of first-year students. Third-year students needed help reaching their final exams, whereas the focus with the first-year students was a more pedagogical approach, with the aim of preventing students from dropping out (Fonnesbæk, 2020b).

Still, some students found the online experience a challenging and lonely one. The solution was for the school to engage both pharmacists and local heads of 
education at the various community pharmacies, focusing on individual guidance (Fonnesbæk, 2020b).

\section{Online exams}

All exams were moved to online provision. The results for the students in their final year showed that written exams proved more challenging, with more students failing their exams, whereas the reverse was the case when it came to oral exams (Table I).

The teachers and censors have reported that more of the students already struggling academically, had difficulties answering the questions in a reflective manner.

The third-year students had an oral examination with a censor that was hosted on Microsoft Teams. Here, the experience was that fewer students than usual failed. The teachers also reported that in general, the students seemed less nervous. Some explained this with the fact that online exams meant less pre-examination chatter since the students did not meet each other. When exams moved online, less nervousness ensued (Fonnesbæk, 2020b).

As was the case with moving the classes online, infrastructure did not prove a problem with regard to the exams. According to school principal Fonnesbæk, only one examination was postponed due to a lack of quality of the Internet connection (Fonnesbæk, 2020b).

Table I: Percentage of students passing their ordinary exams in June

\begin{tabular}{lcc}
\hline & $\mathbf{2 0 1 9}$ & $\mathbf{2 0 2 0}$ \\
\hline $\begin{array}{l}\text { Pharmacy exam - written } \\
\text { interdisciplinary exam }\end{array}$ & $91 \%$ pass & $79 \%$ pass \\
$\begin{array}{l}\text { Counselling exam no 2 - oral } \\
\text { interdisciplinary exam }\end{array}$ & $85 \%$ pass & $91 \%$ pass \\
\hline
\end{tabular}

\section{Back to school}

In September, after the summer break, higher education returned to on-site education. Planning was difficult, as there were no official guidelines when the school had to inform the students what to expect for the autumn semester.

The school updated the infrastructure with solitary tables and planned classes in bigger rooms, made possible by fewer students at a time. The school is a live-in facility with shared bedrooms. Beds were moved, movement flows were organised in the canteen, and each group of students was told which coffee machine to use. Throughout the school, hand sanitiser became available.

Onboarding of new students was a priority. They were planned for two weeks stays, followed by one week of online education. The students in their second year had not been back to the school during lockdown, so it was a priority to see them for a longer period. They also had two weeks stays. For the third-year students, the main priority was to have them start their electives. They had one week of on-site education with a focus on interaction with their co-students, combined with two weeks of online learning.

As the students are also part of the staff at community pharmacies throughout the country and on the Faroe Islands, the change of scheduling concerning the students have had a wider ripple effect of consequences in pharmacies all around (Fonnesbæk, 2020b).

\section{Continuing Professional Education (CPE) and COVID-19}

A similar ripple effect has been caused in the area of CPE. The collective agreements deciding the wages and work hours of Danish pharmaconomists also hold provisions in regard to CPE. It is thus prioritised by both workers and employers. In the spring of 2020, all CPE courses were initially postponed a month and later moved. Some courses were moved online, whereas others, for instance courses in administering vaccinations, were postponed (Rossing, 2020).

In Denmark, CPE courses are offered at the same educational facility housing the pharmaconomist school. Therefore, planning of CPE courses in the fall of 2020 has taken into account the re-arranged foundational training of pharmaconomists. However, through meticulous planning, both the postponed courses from spring of 2020 and the courses originally planned for the fall semester of 2020 have been rescheduled for the fall of 2020, with very few of them further postponed for the spring semester of 2021.

\section{Final summary}

The COVID-19 pandemic and an ensuing national lockdown hit Denmark in March of 2020. The Danish pharmacy sector quickly adjusted both the physical setup in local pharmacies and the management of human resources. All over the country, pharmaconomists worked hard to ensure a low risk of infection whilst ensuring that the critical function of providing medicine to citizens was upheld. In several hospital pharmacies, pharmaconomists were part of the overall emergency response, working closely and seamlessly with all colleagues making things 
run smoothly in an exceptional situation. At the same time, the Danish School of Pharmaconomists, training all Danish pharmaconomists, managed to rapidly convert all courses to online classes, as well as moving all exams online. When lockdown eased, courses were set up in a socially distanced way. With these experiences, both community and hospital pharmacies and the pharmaconomist school are ready to face future lockdowns as part of the Danish 'Hammer and Dance Strategy' to handle the COVID-19 pandemic. Moving forward, it also seems likely that the high level of interprofessional cooperation during the pandemic and the mainly positive experience from moving the education online could influence or inspire both the future role of the pharmaconomists and the educational system.

\section{References}

Danish Health Authority (2020). Sundhedsstyrelsen har lavet nye plakater til butikker og supermarkeder. Available at: https://www.sst.dk/da/Nyheder/2020/Sundhedsstyrelsen-har-lav et-nye-plakater-til-butikker-og-supermarkeder

Fonnesbæk, L. (2020). Personal communication - E-mail dated 11th March 2020

Fonnesbæk, L. (2020). Personal interview - Phone interview dated 7th September 2020

Hagen, E. (2020a). Vi har lavet tiltag så vi kunne holde fysisk afstand til kunderne og bremse smittespredning. Available at: https://www.farmakonom.dk/nyheder/2020/vi-har-lavet-tiltag-sa a-vi-kan-holde-fysisk-afstand-til-kunderne-og-bremse-smettespre dning/

Hagen, E. (2020b). Farmakonom i orkanens øje (online). Available at: https://www.farmakonom.dk/nyheder/2020/farmakonom-iorkanens-oeje/

Hagen, E. (2020c). Vi er fælles i indsatsen mod corona (online). Available at: https://www.farmakonom.dk/nyheder/2020/ vi-er-faelles-om-indsatsen-mod-corona/

Kahns, A., Simonsen, R.L., \& Durinck, C. (2020). Sådan kan apoteket mindske risiko for Corona - krav og inspiration. Available at:https://www.farmakonom.dk/media/1v4g1wdb/faelles-materi ale-fra-foreningerne-om-coronaforholdsregler.pdf

Rossing, C. (2020). Personal interview - Phone interview (2nd September 2020)

The Danish Association of Pharmaconomists (2020). Fleksibilitet skal sikre stabil lægemiddelforsyning. Available at: https:// www.farmakonom.dk/nyheder/2020/fleksibilitet-skal-sikre-stabil-I aegemiddelforsyning/

Wammen, N. (2020). Denmark's Finance Minister Explains Economic Deep Freeze (video). Available at: http://www.pbs.org/ wnet/amanpour-and-company/video/denmarks-finance-ministerexplains-economic-deep-freeze/ 